Conference Paper

\title{
Physicochemical and Organoleptic Characteristics of Seasoning from Tempe Hydrolysates using Long Treatment of Fermentation and Proteolytic Enzyme Proportion
}

\author{
Kalisa Mawarni Putri ${ }^{*}$, Sri Winarti², Sri Djajati² \\ 1Undergraduate student of Department of Food Technology, Faculty of Engineering, Universitas Pem- \\ bangunan Nasional "Veteran" Surabaya, East Java,Indonesia \\ ${ }^{2}$ Lecturer of Department of Food Technology, Faculty of Engineering, Universitas Pembangunan Nasional \\ "Veteran" Surabaya, East Java,Indonesia
}

${ }^{*}$ Corresponding author:

E-mail: kalisamawarni@gmail.com

\begin{abstract}
Tempeh is a native Nusantara food that is often found in traditional Indonesian markets. Over fermentation, due to unsold, they are called over fermented tempeh resulted in non-optimum utilization. Alternative utilizations that can be used is as a seasoning. The making of seasoning can be done by the hydrolysis technique using the protease enzyme of biduri and papain. This study aimed to determine the effect of fermentation time and the proportion of proteolytic enzyme on the physicochemical and organoleptic properties of seasoning from tempeh hydrolysates. The experimental design used was a factorial pattern CRD with two factors. Factor I is tempeh fermentation time (18 hours and 72 hours), while factor II is the enzyme proportion of biduri and papain (0\%: 100\%; 25\%: 75\%; 50\%: 50\%; 75\%: 25\%; and $100 \%$ : $0 \%$ ). The best treatment is 72 hours fermentation duration and the enzyme proportion of biduri and papain (50\%: 50\%) which produces a seasoning powder with the following characteristics: the degree of hydrolysis $82.32 \%$; dissolved protein 58.85\%; moisture 7.89\%; water solubility index 0.09 gr $/ \mathrm{ml}$; oil absorption $0.78 \mathrm{ml} /$ gr, yield $9.32 \%$, organoleptic to taste 3.93 (savory), aroma 3.40 (somewhat pleasant), and color 1.13 (very not white), and glutamic acid content $59,93 \mathrm{mg} / 100 \mathrm{gr}$.
\end{abstract}

Keywords: Seasoning, over-fermented tempeh, hydrolysates of tempeh

\section{Introduction}

Tempeh is used as a main dish for the main source of protein other than meat (Witono et al., 2015 ) by Indonesian people since it contains $18.3 \%$ of protein (Triwibowo, 2011). Tempeh that is sold on the market has a fermentation period of 18-36 hours (Shurtleff \& Aoyagi, 2001) characterized by the presence of white mold and a more compact texture (Owens, 2014). Over fermented ( \pm 72 hours) (Puteri et al., 2018) is characterized by a brownish yellow color, soft texture, and ammonia-like aroma (Mujianto et al., 2018). This tempeh is often added as a seasoning for some traditional Javanese foods (Muzdalifah et al., 2017). But its utilization is not optimal because of the distinctive taste and aroma that is less favorable therefore, most of them are thrown or used as animals' food.

A recent study from Puteri et al., (2015) showed that the composition of glutamic acid in overfermented tempeh was $15.9 \%$ higher compared to fresh tempeh. Over-fermented tempeh which was further hydrolyzed using the exopeptidase from calotropin in Witono et al. (2015) produced glutamic acid up to 55.84\%. Hydrolysis at a certain level according to Subagio et al. (2002) can

\section{How to cite:}

Putri, K. M., Winarti, S., \& Djajati, S. (2020). Physicochemical and organoleptic characteristics of seasoning from tempe hydrolysates using long treatment of fermentation and proteolytic enzyme proportion. $1^{\text {st }}$ International Conference Eco-Innovation in Science, Engineering, and Technology. NST Proceedings. pages 76-85. doi: 10.11594/ nstp.2020.0511 
improve the organoleptic quality of tempeh hydrolysate with a savory taste. Tavano (2013) stated that protein hydrolysis using specific proteases is expected to change nutritional features including increased digestibility and modification of taste quality.

The combination of endopeptidase and exopeptidase is known to synergize well to produce short-chain peptides and high amino acid for the production of koro pedang flavor enhancers (Witono, 2014). Papain sourced from papaya latex contains 45\% kimopapain, $10 \%$ papain, and $20 \%$ lysozyme which is known to have wide specificity (Storer \& Menard, 2013) to produce more short-chain peptide fragments that function as further hydrolysis by exopeptidase. Biduri which is indicated in the exopeptidase group cuts the peptide bonds at the end of the substrate (Witono, 2013). The specificity of biduri cutting is on the peptide bond contains acid residues namely glutamic acid (Sengupta et al., 1984). Making seasoning from tempeh in powder form can extend the storing duration and increase practicality. Therefore, it can increase the chance of utilizing seasoning from tempeh hydrolysate in various processed products such as soups, biscuits, snacks, and supplements for other products to enrich nutrients.

\section{Research Method \\ Materials}

The raw ingredients used in this study are tempeh with 18 hours fermentation time marked by white mold and compact texture, and over-fermented tempeh of 72 hours fermentation time characterized by a brownish yellow color, soft texture, and ammonia-like aroma obtained from tempeh craftsmen of Kelurahan Trenggilis, Surabaya. Additional ingredients used including biduri latex obtained from the Gunung Anyar garden, papaya latex obtained from the Pandugo papaya orchards, Na-metabisulfite, $\mathrm{HCl}$, maltodextrin, glucose, and salt. The ingredients used for the analysis were tyrosine standard, soluble casein, phosphate buffer $\mathrm{pH} \mathrm{7,} \mathrm{trichloroacetic} \mathrm{acid} \mathrm{(TCA),}$ Lowry reagent, Folin-Ciocalteu reagent, Bovine Serum Albumin (BSA) standard, glutamic acid standard $10 \mathrm{pmol}$, and cooking oil.

\section{Procedures}

Production of crude biduri enzyime extracts

The biduri latex is collected in a $12^{\circ} \mathrm{C}$ distilled water containing $0.7 \% \mathrm{Na}$-metabisulfite $\mathrm{pH} 3.5$ with a ratio between the latex and Na-metabisulfite solution of 1:4 (v/v). Furthermore, centrifugation at $3000 \mathrm{rpm}$ room temperature for 20 minutes. The sludge is crude biduri enzyme extract which is then tested for its protease activity.

\section{Production of crude papain enzyme extracts}

The young papaya latex is collected in aquades containing $0.7 \% \mathrm{Na}$-metabisulfite with a ratio between the latex and Na-metabisulfite solution of 1: 4 (v/v). Moreover, centrifugation at 3000 rpm room temperature for 20 minutes. The sludge is a crude extract of papain enzyme which is then tested for its protease activity.

\section{Preparation of samples}

Tempeh was steamed at $100^{\circ} \mathrm{C}$ for $10 \mathrm{~min}$ and mashed by blender with the addition of water $(2: 1)(\mathrm{v} / \mathrm{b})$. The material was then hydrolyzed at $55^{\circ} \mathrm{C}$ and $\mathrm{pH} 7$ for 3 hours with the enzyme addition of $3 \%$ (proportion according to factor II), then boiled at $100^{\circ} \mathrm{C}$ for $10 \mathrm{~min}$ to the inactivated enzyme. After that be centrifuged at $3000 \mathrm{rpm}$ at room temperature for $10 \mathrm{~min}$, and taken the supernatant. The resulting supernatant is analyzed and the degree of hydrolysis is then mixed with $6 \%$ glucose $(\mathrm{w} / \mathrm{v}), 1 \%$ salt $(\mathrm{w} / \mathrm{v})$, and maltodextrin $12.5 \%$ of the supernatant volume. Then it is dried at $60^{\circ} \mathrm{C}$ for 8 hours. The resulting powder is then grounded and sieved using an 80 mesh sieve. 


\section{Results and Discussion Proteolytic activity}

Tempeh was steamed at $100^{\circ} \mathrm{C}$ for $10 \mathrm{~min}$ and mashed by blender with the addition of water $(2: 1)(\mathrm{v} / \mathrm{b})$. The material was then hydrolyzed at $55^{\circ} \mathrm{C}$ and $\mathrm{pH} 7$ for 3 hours with the enzyme addition of $3 \%$ (proportion according to factor II), then boiled at $100^{\circ} \mathrm{C}$ for $10 \mathrm{~min}$ to the inactivated enzyme. After that be centrifuged at $3000 \mathrm{rpm}$ at room temperature for $10 \mathrm{~min}$, and taken the supernatant. The resulting supernatant is analyzed and the degree of hydrolysis is then mixed with $6 \%$ glucose $(\mathrm{w} / \mathrm{v}), 1 \%$ salt $(\mathrm{w} / \mathrm{v})$, and maltodextrin $12.5 \%$ of the supernatant volume. Then it is dried at $60^{\circ} \mathrm{C}$ for 8 hours. The resulting powder is then grounded and sieved using an 80 mesh sieve.

Table 1. The test result of crude papain and biduri enzyme activities

\begin{tabular}{ccc}
\hline \multirow{2}{*}{ Enzyme } & \multicolumn{2}{c}{ Enzyme Activity (Unit) } \\
\cline { 2 - 3 } & Result & Literature \\
Crude Papain & $1.045 \pm 0,031$ & $0.919^{*}$ \\
Crude Biduri & $1.186 \pm 0,046$ & $0.946^{* *}$ \\
\hline
\end{tabular}

Source: *Ratnayani dkk (2015); **Raharjo (2012)

The addition of Na-metabisulfite solution can reduce disulfide bonds whereas it increased its activity and with a concentration of $0.7 \%$ prevented enzyme damage due to oxidation. This is following Kusumastyaningrum (2002) which stated that the addition of reducing compounds such as sodium metabisulfite can activate the papaya latex. The use of $0.7 \%$ sodium metabisulfite according to Witono (2013) is also an antioxidant that can prevent damage to papain due to oxidation by the air.

The addition of the antioxidant Na-metabisulfite $0.7 \%$ in biduri latex was carried out not only to prevent oxidation but also to increase its activity by reducing disulfide bonds. This is following Witono (2013) that biduri enzyme is sulfhydryl protease which activity is inhibited if the sulfhydryl group is oxidized, the addition of Na-metabisulfite acts as an antioxidant and increases enzyme activity because it can reduce disulfide bonds.

\section{Degree of hydrolysis}

The degree of hydrolysis is a parameter that can be used to monitor the hydrolysis process because it states the percentage of peptide bonds released due to the hydrolysis process (Silvestre et al., 2013). Based on variance analysis, there is a real interaction ( $\mathrm{p} \leq 0.05)$ between the fermentation time and the proportion of enzyme to the degree of hydrolysis. Figure 1 . shows that the longer the fermentation and the higher the proportion of the enzyme papain added, the more the degree of hydrolysis increases.

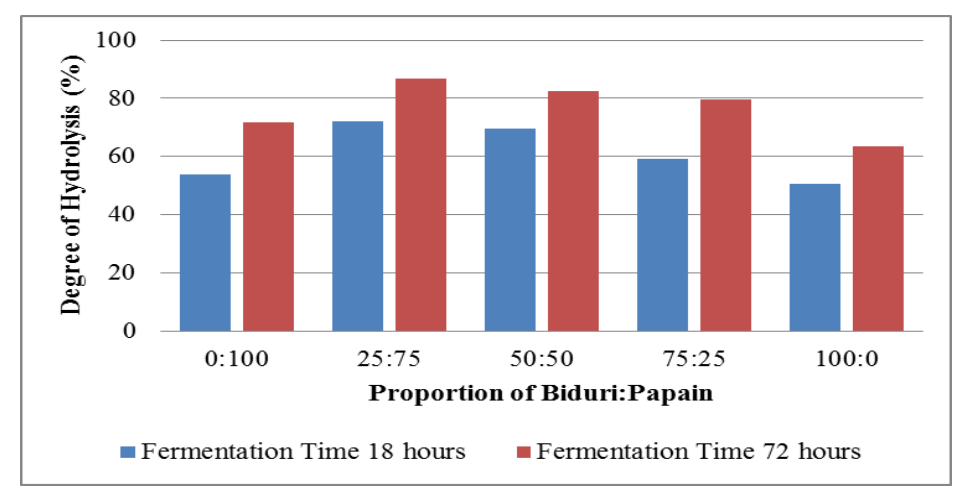

Figure 1. Degree of hydrolysis of tempeh hydrolysate with fermentation duration and enzyme proportion treatments 
The longer fermentation causes the further process of hydrolysis by molds thus increasing the short-chain peptide which results in an increasing degree of hydrolysis value. This is following Rahayu et al. (2019) that the degree of hydrolysis of the swollen tempeh koro has increased sharply in the first 24 hours, the longer incubation slightly increases the degree of hydrolysis but not as sharp at the beginning of fermentation, then after 48 hours of fermentation, the percentage of hydrolyzed protein is relatively stable (around 45\%). Increased papain addition can increase the degree of hydrolysis because papain from papaya latex is an endopeptidase containing $10 \%$ papain enzyme and $45 \%$ kimopapain which makes papain from papaya latex have a high hydrolytic ability. Combined with the enzyme biduri can increase the degree of hydrolysis because the enzyme bidur as exopeptidase cuts peptide bonds resulting from cutting papain at the end. This is following the study of Xu et al., (2019) that endopeptidases hydrolyzes proteins and increases the amount of $\mathrm{N}$-terminal for further hydrolysis by exopeptidase.

\section{Dissolved protein levels}

Based on the analysis of variance there is a real interaction $(\mathrm{p} \leq 0.05)$ between the fermentation time and the proportion of enzymes to protein content. Figure 2. shows that the longer the fermentation and the higher the proportion of the enzyme papain added it can increase levels of dissolved protein.

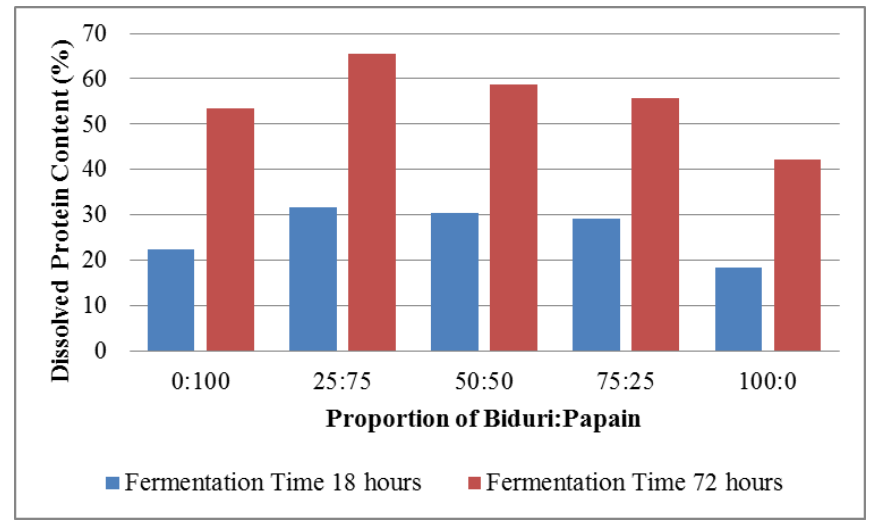

Figure 2. Dissolve protein content of seasoning from tempeh hydrolysate with fermentation duration and enzyme proportion treatments.

During fermentation, macronutrient degradation becomes a component of the peptide, the longer the fermentation time is up to 72 hours according to Utami (2014), the peptide component is further broken down into components having a smaller molecular weight (Nount and Kiers, 2005). However, if the proportion of papain is lowered, then the level of dissolved protein also decreases with the degree of hydrolysis. That is because papain produces peptides by cutting the protein in the middle, then the peptide will be used as a substrate by biduri enzyme to produce shorter peptides that get higher so that the degree of hydrolysis increases. If the proportion of papain is reduced, then the availability of the substrate for biduri enzyme is reduced so that the short peptides produced are low, which resulted in a decreased degree of hydrolysis. This is following Witono et al., (2014) that the availability of short-chain protein decreases with the decreasing proportion of the papain enzyme. In Witono's study (2014) the ratio of biduri and papain to produce the highest levels of dissolved protein is 2:3.

\section{Moisture content}

Based on the analysis of variance there is a real interaction $(p \leq 0.05)$ between the fermentation time and the ratio of enzymes. Figure 3. shows that the longer the fermentation and the higher the ratio of papain enzyme added, it can increase the moisture. 


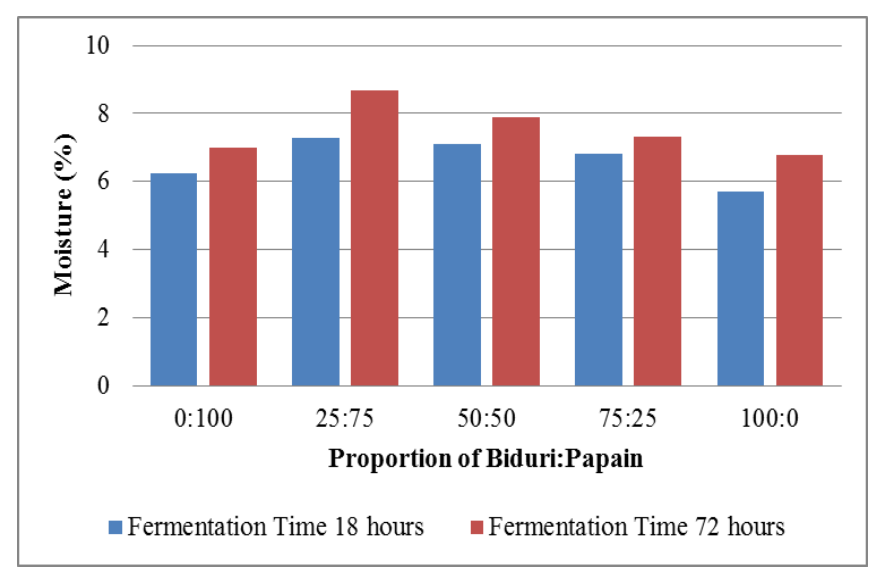

Figure 3. The moisture content of seasoning from tempeh hydrolysate with fermentation duration and enzyme proportion treatments.

This is related to the level of dissolved protein which shows a lot of hydrophilic cluster peptides and amino acids so that the level of binding of water is high. This is following Witono's research (2014) that with the treatment of biduri and papain enzymes with a ratio of 2:3, produces flavor enhancers with the highest moisture of 10.51\%. According to Haurowitz \& Koshland (2020) hydration or binding of this water occurs in proteins with hydrophilic groups, especially positively charged groups on the side chains of lysine and arginine and negatively charged groups on aspartic and glutamic acid groups. Hydration can also occur in the hydroxyl groups $(-\mathrm{OH})$ serine and threonine or in the asparagine and glutamine groups in amides $\left(-\mathrm{CONH}_{2}\right)$.

\section{Water solubility index}

Water solubility index is the ability of flavor enhancers to dissolve in water which is associated with the functional properties of proteins (Estiasih \& Ahmadi, 2009), especially as a seasoning. Variance analysis showed low results on significant oil binding capacity of interaction $(p \leq 0.05)$ between fermentation time and enzymes ratio. Figure 4. shows that the longer the fermentation and the higher the proportion of the enzyme papain added, the more moisture can be increased.

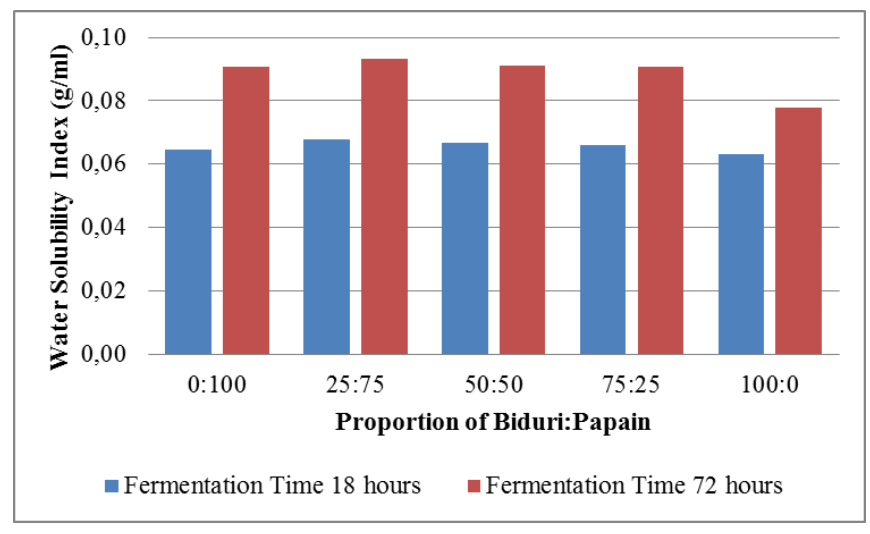

Figure 4. Water solubility index of seasoning from tempeh hydrolysate with fermentation duration and enzyme proportion treatments.

This is because, during fermentation, macronutrient degradation becomes shorter peptide components so that the longer the fermentation time up to 72 hours an increase in short peptides 
according to Utami (2014) which has smaller molecular weights with higher water solubility (Nount \& Kiers, 2005).

The treatment using biduri and papain enzymes ratio was resulted in a higher water solubility index compared to the results of Wijayanti (2016) with a water solubility index of $0.059 \mathrm{gr} / \mathrm{ml}$ of flavor enhancer hydrolysate protein in the treatment of wader fish $50 \%$ protein hydrolysate:50\% ingredients). The higher the proportion of papain added, the higher the water solubility index. This is related to the level of dissolved protein, treatment with the proportion of enzymes produces high levels of dissolved protein which shows a lot of peptides and polar amino acids so that this affects the solubility in water. This is following Chen et al., (2011) which stated that enzymatic hydrolysis increases polar groups that can interact with water through hydrogen bonds so that their solubility increases.

\section{Oil absorption}

The functional properties of powders are usually related to interactions between water and oil. Based on variance analysis, there was no real interaction $(p \leq 0.05)$ between the fermentation time and enzymes ratio.

Table 2. The oil absorption of seasoning from tempeh hydrolysate with fermentation duration treatments

\begin{tabular}{cc}
\hline Fermentation Duration & $\begin{array}{c}\text { Oil Absorption } \\
\text { (ml/gr) }\end{array}$ \\
\hline 18 Hours & $2.243 \pm 0.106^{\mathrm{b}}$ \\
72 Hours & $1.642 \pm 0.176^{\mathrm{a}}$ \\
\hline
\end{tabular}

Note: The average value issued by the same letter means that it is not significantly different at $p \geq 0.05$

Table 2. shows that the longer the fermentation time, the lower the oil binding capacity. The oil binding capacity is related to the level of dissolved protein. High levels of the dissolved protein indicate low hydrophobicity so that the oil binding capacity is low. This is following Kristinsson \& Rasco (2000) that the binding capacity of protein oils also correlates with hydrophobicity surface. The treatment of enzymes ratio gives a real influence on the absorption of flavoring oils from tempeh hydrolysate.

Table 3. The oil absorption of seasoning from tempeh hydrolysate with enzyme proportion treatments

\section{Proportion \\ Biduri:Papain (\%)}

\section{oil absorption (ml/gr)}

\begin{tabular}{ll}
\hline $0: 100$ & $1.960 \pm 0.578^{\mathrm{b}}$ \\
$25: 75$ & $1.844 \pm 0.435^{\mathrm{a}}$ \\
$50: 50$ & $1.860 \pm 0.404^{\mathrm{a}}$ \\
$75: 25$ & $1.881 \pm 0.440^{\mathrm{a}}$ \\
$100: 0$ & $2.167 \pm 0.268^{\mathrm{c}}$ \\
\hline
\end{tabular}

Note: The average value issued by the same letter means that it is not significantly different at $\mathrm{p} \geq 0.05$.

Table 3. shows that enzymes ratio with high papain addition shows low oil absorption. The capacity to absorb oil is related to the level of dissolved protein, high levels of the dissolved protein indicate the presence of polar clusters and amino acids so that this affects the binding capacity of the weakened oil. This is following Wouters et al., (2016) that enzymatic hydrolysis decreases the ability of fat binding because the hydrolysis process liberates polar clustered of amino acids. 


\section{Yield}

Based on variance analysis, there is a real interaction $(\mathrm{p} \leq 0.05)$ between the fermentation time and enzyme ratio to the yield.

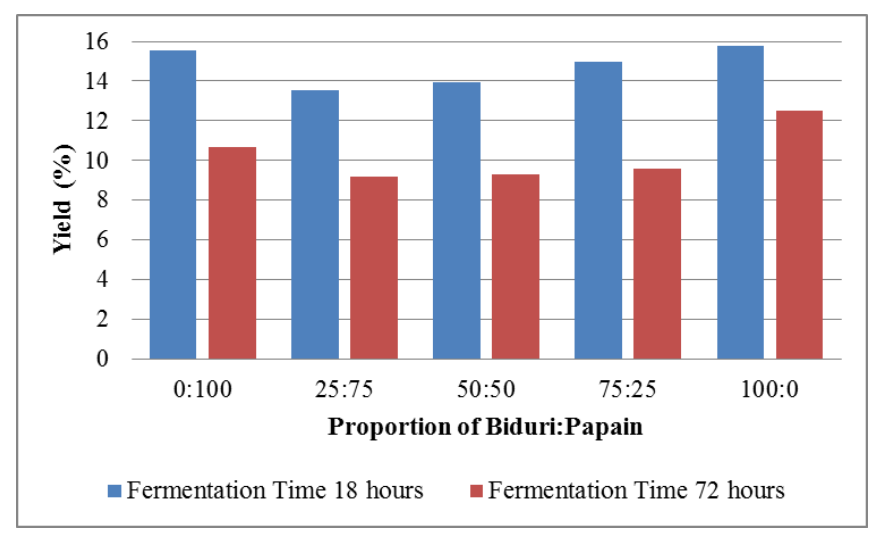

Figure 5. The yield of seasoning from tempeh hydrolysate with fermentation duration and enzyme proportion treatments.

Figure 5. shows that the longer the fermentation and the higher the proportion of papain added, the lower the yield. This is because the longer the fermentation time, the more water-insoluble solids the higher. This is following Utami (2016) that more than $90 \%$ of further fermented tempeh consists of solids that are not water-soluble. So that the resulting supernatant is lower which results in the yield of seasoning powder is low.

Treatment with a high proportion of the papain enzyme shows a low yield. This is related to the degree of hydrolysis, the hydrolysis reaction requires water $\left(\mathrm{H}_{2} \mathrm{O}\right)$. The treatment of biduri and papain enzymes ratio shows a high degree of hydrolysis so that the need for water is higher which resulted in water remaining after the hydrolysis process decreases, resulting in a low supernatant yield so that the yield of seasoning powder is low. This is following Patton (2019) that hydrolysis is a catabolic reaction that requires water to break down large molecules into smaller molecules.

\section{Organoleptic}

Table 4. Mean organoleptic of seasoning from tempeh hydrolysate with fermentation duration and enzyme proportion treatments

\begin{tabular}{ccccc}
$\begin{array}{c}\text { Time Fermenta- } \\
\text { tion (hours) }\end{array}$ & $\begin{array}{c}\text { The proportion } \\
\text { of Biduri: Pa- } \\
\text { pain }\end{array}$ & $\begin{array}{c}\text { The score of } \\
\text { taste }\end{array}$ & $\begin{array}{c}\text { The score of } \\
\text { aroma }\end{array}$ & $\begin{array}{c}\text { The score of a } \\
\text { color }\end{array}$ \\
\hline 18 & $0: 100$ & $2.2 \pm 0.561$ & $1.4 \pm 0.507$ & $3.6 \pm 0.507$ \\
& $25: 75$ & $2.6 \pm 0.828$ & $1.8 \pm 0.941$ & $3.4 \pm 0.507$ \\
$50: 50$ & $2.8 \pm 0.862$ & $1,7 \pm 0.617$ & $3.5 \pm 0.516$ \\
$75: 25$ & $2.3 \pm 0.488$ & $1.6 \pm 0.828$ & $3.5 \pm 0.516$ \\
$100: 0$ & $2.1 \pm 0.704$ & $1.3 \pm 0.488$ & $3.6 \pm 0.488$ \\
& $0: 100$ & $3.5 \pm 0.516$ & $3.1 \pm 0.258$ & $1.3 \pm 0.488$ \\
72 & $25: 75$ & $3.5 \pm 0.516$ & $3.6 \pm 0.488$ & $1,1 \pm 0.258$ \\
& $50: 50$ & $3.9 \pm 0.596$ & $3.4 \pm 0.507$ & $1,1 \pm 0.352$ \\
& $75: 25$ & $3.7 \pm 0.617$ & $3.3 \pm 0.458$ & $1,2 \pm 0.414$ \\
$100: 0$ & $3.3 \pm 0.488$ & $2.9 \pm 0.458$ & $1,4 \pm 0.507$ \\
\hline
\end{tabular}


Table 4. shows that the longer the fermentation and the higher papain ratio added, it resulted in savory flavor and pleasant aroma score but the more color scores that are not white. The fermentation process during the manufacture of tempeh produces a distinctive flavor forming component, both flavor components that contribute to taste and aroma. During tempeh fermentation, microbes play an important role in producing organoleptic qualities of tempeh since microbes (mold) can hydrolyze proteins into free amino acids and peptides enzymatically (Handoyo \& Morita 2006). However, excessive fermentation of up to \pm 72 hours at room temperature will cause damage that is marked with brownish-yellow (Mujianto et al., 2018) so that the resulting seasoning powder is brown.

The higher ratio of papain added it resulted in a less savory flavor score. This is presumably because of the high degree of hydrolysis which can produce a bitter flavor that can mask the savory flavor. This is following Sukkhown et al, (2017) which stated that increasing the degree of hydrolysis hydrolysate solution was produced with a bitter flavor so that the overall preference score is reduced. The degree of hydrolysis is one of the factors that regulate the intensity of bitterness. The more hydrolysis, the higher the level of degradation of protein structures and the more hydrophobic peptides that increase the bitter flavor (Fu et al., 2018). Besides papain as endopeptidase in the study of Fu et al., (2018) can cause a bitter flavor, an optimal mixture of endoand exo-peptidase can produce hydrolysate with a low bitter flavor.

Treatment with a high proportion of papain produces an increasingly pleasant aroma score. This aroma is related to the degree of hydrolysis, the higher the degree of hydrolysis, the higher the components of peptides and amino acids that contribute to flavor. This is following Witono (2014) that the aromas formed can be generated from additional sugar, free amino acids, peptides, nucleotides, and organic acids that act as the main precursors in the formation of savory flavors in the flavor enhancers produced.

Treatment with a higher papain ratio results in increasingly white color. This shows that a higher papain ratio results in higher levels of dissolved protein with brown powder as the final product. This is following Sukkhown et al., (2017) which stated that an increase in protein content in the solution will produce a dark brown solution. According to Kotlar et al., (2013) enzymatic hydrolysis reaction contributes to the reduction in brightness and gives a darker appearance of hydrolysate.

\section{Glutamic acid content}

The content of the glutamic acid of raw ingredients and the best samples can be seen in Table 5. The level of glutamate of raw ingredients in this study is lower compared to the results of the research of Puteri et al., (2015). This difference is due to the difference in fermentation time. During fermentation, macronutrient degradation becomes a simpler component.

Table 5. Test result of glutamic acid content

\begin{tabular}{|c|c|c|}
\hline \multirow{2}{*}{ Sample } & \multicolumn{2}{|c|}{ Asam Glutamate (mg/100g) } \\
\hline & Result & Literature \\
\hline Fermentation 18 hours & $10,899 \pm 0,044$ & 14,53 \\
\hline Fermentation 72 hours & $13,782 \pm 0,044$ & 15,90 \\
\hline A2B3 & $59,930 \pm 0,033$ & 55,84 \\
\hline
\end{tabular}

Source: *Puteri et al., (2015); **Witono et al., (2015)

The faster the fermentation time, the lower the simple components formed. This is supported by Rahayu et al. (2019) which showed that the total amount of hydrolyzed soy protein increases with the length of time of fermentation, so that total nitrogen and water-soluble amino acids increase (Puteri et al., 2018). 
The glutamic acid level in A2B3 treatment was greater than the results of research by Witono et al., (2015). This difference is due to the study of Witono et al., (2015) hydrolysis treatment using only the biduri enzyme. Meanwhile, according to Vogel \& May (2019), to produce improved properties, synergism is needed through the use of a combination of proteases from various biological sources that are used sequentially or in parallel. The biduri enzyme as exopeptidase in breaking terminal peptide bonds from whole globular proteins requires preliminary treatment or combination with endopeptidase, namely papain to open globular structures and expose terminals.

\section{Conclusion}

The seasoning from tempeh hydrolysate increased the glutamic acid content was able to be used as a seasoning product.

\section{Acknowledgment}

We would like to thanks Allah SWT and parents.

\section{References}

Chen, L., Chen, J., Ren, J., \& Zhao, M. (2011). Effects of ultrasound pretreatment on the enzymatic hydrolysis of soy protein isolates and on the emulsifying properties of hydrolysates. Journal of Agricultural and Food Chemistry, 59(6), 2600-2609.

Fu, Y., Chen, J., Bak, K.H., \& Lametsch, R. (2018). Valorisation of Protein Hydrolysates from Animal by-Products: Perspectives on Bitter Taste and Debittering Methods: A Review. International Journal of Food Science and Technology, 2018, 35-40.

Handoyo, T., \& Morita, N. (2006). Structural and functional properties of fermented soybean (tempeh) by using Rhizopus oligosporus. International Journal of Food Properties, 9,347-55.

Haurowitz, F. \& Koshland, D.E. (2020). Hydration of proteins. Retrieved June 27, 2020. From https://www.britannica.com/science/protein/Hydration-of-proteins.

Kotlar CE, Ponce AG, \& Roura SI. (2013). Improvement of Functional and Antimicrobial Properties of Brewery by Product Hydrolyzed Enzymatically. LWT Food Sci Technol, 50, 378-85.

Kristinsson, H.G., \& Rasco, B.A. (2000). Fish protein hydrolysates: production, biochemical, and functional properties. Critical Review in Food Science and Nutrition, 40,43-81.

Kusumastyaningrum, D. (2002). Pengaruh antioksidan dan aktivator untuk mempertahankan aktivitas proteolitik getah pepaya selama penyimpanan. Skripsi: Institut Pertanian Bogor.

Mujianto, Witono, Y., Wignyanto, Kumalaningsih, S., \& Auliani'am. (2018). Hydrolysis Characteristics of Over Fermneted Tempe (Fermneted Soybean Cake) Product Hydrolyzed by Enzymatic Hydrolyzed as Natural Flavor Source (Flavor Enhancer). The Indian Journal of Nutrition and Dietetics, 55(1), 29-43.

Muzdalifah, D., Athaillah, Z.A., Nugrahani, W., \& Devi, AF. (2017). Colour and pH Changes of Tempe During Extended Fermentation. International Symposium on Applied Chemistry (ISAC),1-9

Nount M.J.R. \& Kiers J.L. (2005). A Review. Tempe Fermentation, Innovation and Functionality : Update Into The Third Millenium. Journal of Applied Microbiology, 98, 789-805.

Owens, J. D. (2014). Indigenous fermented foods of Southeast Asia (1st edition). Amerika: CRC Press. pp.25.

Patton. (2019). anatomy \& physiology (includes A\&P Online course). St. Louis: Elsevier. pp.46

Puteri, M.D.P.T.G., Hassanein, T.R., Prabawati, E.K., Wijaya, C.H., \& Mutukumira, A.N. (2015). Sensory characteristics of seasoning powders from overripe tempeh, a solid state fermented soybean. J. Procedia Chemistry, 14, 263-269.

Puteri, M. D. P. T. G., Fortunata, S. A., Prabawati, E. K., Kristianti, F., \& Wijaya, C. H. (2018). Overripe tempe as source of protein in development of ready to eat porridge. International Food Research Journal, 25 (2), S201-S209.

Raharjo, NP. (2012). Pengaruh penggunaan getah biduri (Calotropis gigantea) terhadap kualitas fisik dan kimia keju asal susu kambing. Skripsi.: Universitas Sebelas Maret.

Rahayu, N.A., Cahyanto, M.N., \& Indrati, R. (2019). Pola perubahan protein koro benguk (mucuna pruriens) selama fermentasi tempe menggunakan inokulum raprima. J. Agritech, 39 (2), 128-135.

Ratnayani, K., Juwarni, A. A. S., Laksmiwati, A. M., \& Dewi, I. G. K. S. P. (2015). Uji aktivitas protease getah labu siam dan talas serta Perbandingannya terhadap getah pepaya. Jurnal Kimia, 9 (2), 147-152. 
Sengupta, A., Bhattacharya, D., Pal, G., \& Sinha, N.K. (1984). Comparative studies on calotropis DI and DII from The Latex of Calotropis gigantea. J. Biochemistry and Biophysics, 232 (1), 17-25.

Shurtleff, W. \& Aoyagi, A. (2001). The book of tempeh (2nd edition). Berkeley: Ten Speed Press. pp. 146.

Silvestre, M. P. C., Morais, H. A., Silva, V. D. M., \& Silva, M. R. (2013). Degree of hydrolysis and peptide profile of whey proteins using pancreatin. J. Brazilian Soc. Food Nutr, 38(3), 278-290.

Storer, A.C. \& Menard, R. (2013). Handbook of proteolytic enzymes. USA: Elsevier. pp.1859.

Subagio, A., Hartanti, S., Windrati, W.S., Unus, Fauzi, M., \& Herry, B. (2002). Kajian sifat fisikokimia dan organoleptik hid rolisat tempe hasil hidrolisis protein. J. Teknologi dan Industri Pangan, 8(3), 204-210.

Sukkhown, P., Jangchud, K., Lorjaroenphon, Y., \& Pirak, T. (2017). Flavored-functional protein hydrolysates from enzymatic hydrolysis of dried squid by-products: Effect of drying method. Food Hydrocolloids, $x x x, 1-10$.

Tavano, U.L. (2013). Protein hydrolysis using proteases: an important tool for food biotechnology. Journal of Molecular Catalysis Enzymatic, 90, 1-11.

Triwibowo, R. (2011). Kajian perubahan biokimiawi stakhiosa dan asam lemak essensial pada tempe kedelai (Glycine max) selama proses fermentasi. Skripsi: Universitas Sebelas Maret. Surakarta.

Utami, R. (2014). Karakterisasi komponen pembentuk rasa yang terdapat dalam ekstrak larut air tempe terfermentasi lanjut. Tesis: IPB.

Utami, R., Wijaya, C.H., \& Lioe H.N. (2016). Taste of Water-Soluble Extracts Obtained from Over-Fermented Tempe. International Journal of Food Properties, 19, 2063-2073.

Vogel, A., \& May, O. (2019). Industrial enzyme applications. Jerman: wiley-VCH. p:128-129

Wijayanti, R.P. (2016). Formulasi flavor enhancer dari hidrolisat protein ikan wader. Skripsi. Universitas Jember.

Witono.Y. (2013). Enzim biduri: Agen aktif potensial untuk proses pangan. Surabaya: Pustaka Radja, p.1-91.

Witono, Y. (2014). Teknologi flavor alami berbasis proses hidrolisis enzimatis. Surabaya: Pustaka Radha,p. 5-76

Witono, Y., Windrati, W., Taruna, I., Afriliana, A., \& Assadam, A. (2014). Production and characterization of protein hydrolyzate from "Bibisan Fish" (Apogon Albimaculosus) as an indigenous flavor by enzymatic hydrolysis. Advance Journal of Food Science and Technology, 6, 1348-1355.

Witono, Y., Widjanarko, S.B., Mujianto, \& Rachmawati, D.T. (2015). Amino acid identification of over fermented tempeh, the hydrolysate and the seasoning product hydrolysed by calotropin from crown flower (Calotropis gigantea). International Journal Of Advanced Science Enginering Information Technology, 5(2), 103-106.

Wouters, A.G.B. , Rombouts, I, Fierens, E., Brijs, K. \& Delcour, J.A. (2016). Relevance of the functional properties of enzymatic plant protein hydrolysates in food systems. Comprehensive Reviews in Food Science and Food Safety, 15, 786-800.

Xu, Y., Galanopoulos, M., Sismour, E., Ren, S., Mersha, Z., Lynch, P., \& Almutaimi, A. (2019). Effect of Enzymatic Hydrolysis Using Endoand Exo-Proteases on Secondary Structure, Functional, and Antioxidant Properties of Chickpea Protein Hydrolysates. Journal of Food Measurement and Characterization, 14(1), 343-352. doi: https://doi.org/10.1007/s11694-019-00296-0. 